\title{
ТЕОРЕТИКО-МЕТОДОЛОГІЧНІ ЗАСАДИ ФОРМУВАННЯ МЕХАНІЗМУ ЗАБЕЗПЕЧЕННЯ ЕКОНОМІЧНОЇ БЕЗПЕКИ ПІДПРИСМСТВА
}

\author{
Полтавська державна аграрна академія
}

Формування у підприємстві дієвої системи економічної безпеки і організація ії успішної реалізації повинні базуватися на методологічних аспектах наукової теорії безпеки та включати певні заходи, що здійснюється поетапно в певній послідовності або одночасно. Їх сукупність утворює механізм забезпечення економічною безпекою підприємства як сукупність правових норм, законодавчих актів, спонукальних мотивів і стимулів, заходів, методів, засобів і сил, за допомогою яких забезпечується досягнення цілей безпеки і вирішення поставлених завдань.

У статті обгрунтовано актуальність необхідності формування ефективного механізму забезпечення економічної безпеки підприємства, якому відводиться пріоритетна роль у загальному управлінні безпекою суб'єкта господарювання. Здійснено аналіз наукових досліджень різних дослідниківекономістів, який свідчить про невизначену точку зору, щодо трактування поняття «механізм забезпечення економічної безпеки підприємства». Визначено, що найбільш значимим структурним елементом механізму забезпечення економічної безпеки підприємства $\epsilon$ системне забезпечення управління економічною безпекою підприємства, куди входить нормативно-правове, інформаційне, організаційне, методичне та ресурсне забезпечення. Зокрема, досліджено суб'єкти і об'єкти, функції, завдання, принципи, методи забезпечення економічної безпеки підприємства. Розглянуто особливості, мету формування та основні елементи механізму забезпечення економічної безпеки підприємства.

Ключові слова: безпека, економічна безпека підприємства, механізм, загрози і небезпеки, чинники впливу, принциии, захист, механізм забезпечення економічної безпеки підприємства.

\section{MECHANISM OF ENSURING ECONOMIC SECURITY OF ENTERPRISE: THEORETICAL AND METHODOLOGICAL FUNDAMENTALS OF ITS FORMATION}

\author{
Poltava State Agrarian Academy
}

The development of an effective system of economic security at the enterprise and organization of its successful implementation should be based on the methodological aspects of the scientific theory of security and include the measures carried out step-by-step, in proper sequence, or simultaneously. Their combination creates a mechanism for ensuring the economic security of the enterprise. It can be defined as a set of legal norms, legislative acts, motivational motives and incentives, measures, methods, tools, and forces, owing to which an enterprise can achieve security goals and solve the tasks.

The article substantiates the urgency of implementing an effective mechanism for ensuring the economic security of the enterprise, which plays a top priority role in the overall security management of the business entity. The author provides an analysis of the scientific papers of various researchers-economists, which manifests some uncertainty regarding the interpretation of the concept of "mechanism for ensuring the economic security of the enterprise". The study has revealed that the most important structural element of the security mechanism of enterprise is the management system of the enterprise economic security, which includes regulatory, informational, organizational, methodological, and resource support. In a focus of the research are the subjects, objects, functions, tasks, principles, and methods of ensuring the economic security of an enterprise. The emphasis is on the features, purpose of formation, and the basic elements of the mechanism of maintaining the enterprise economic security. The enterprise economic security mechanism, developed on the basis of scientific approaches, principles, methods, and leverage, indicates the plurality of its components and confirms the complexity of the security formation process on the whole.

Key words: security, economic security of the enterprise, mechanism, threats and dangers, factors of influence, principles, protection, mechanism of ensuring economic security of the enterprise.

Постановка проблеми у загальному вигляді i iї зв'язок з важливими науковими та практичними завданнями. Проблема забезпечення економічної безпеки ніколи не втрачає своєї актуальності ні в масштабах країни, ні в окремо взятому 
підприємстві. У зв'язку з переходом до ринкової системи господарювання ця проблема стала надзвичайно важливою. Умови, за яких існування економічних ризиків та витрат, пов'язаних із ними є об'єктивними і зумовлюють формування механізму, який міг би дозволити як найкраще, з точки зору цілей, які ставить керівництво підприємства, ідентифікувати ризики і при можливості знешкодити його при прийнятті управлінських рішень.

Аналіз останніх досліджень, у яких започатковано вирішення проблеми. Аналіз останніх досліджень і публікацій, свідчить про те, що дану проблематику досліджували в своїх наукових працях такі провідні науковці, як I.O. Бланк, К.С. Горячева, М.М. Єрмошенко, А.В. Козаченко, М.І. Круглов, В.С. Пономаренко та інші. Дослідженню питань забезпечення економічної безпеки суб' єктів господарювання та формування його механізму присвячено достатньо праць фахівців, таких як Н.В. Білошкурська [1], Л.П. Гончаренко, Е.С. Куценко [2], Л.І. Донець, Н.В. Ващенко [3], Д.В. Дячков [4], Н.П. Левковець [5], Ю.А. Локтіонова [6], І.А. Маркіна [7], С.Г. Міщенко [8], О. Орлик [9], Н.А. Протопопова [10], В.І. Торкатюк, А. Аболхасанзаде, Т.В. Мітіна, I.О. Козинська, Н.І. Кузічкіна, Н.В. Дріль [11], І.Л. Шевченко [12], Л. Юрович [13]. Сформульовані в їхніх працях наукові концепції, положення, рекомендації та висновки займають важливе місце у сучасній теорії економічної безпеки підприємств і дозволяють найкращим чином усвідомити важливість і складність вирішення означеної проблеми.

Ціль статті - дослідити теоретико-методологічні засади формування механізму забезпечення економічної безпеки підприємства.

Виклад основного матеріалу дослідження 3 повним обгрунтуванням отриманих наукових результатів. Економічна безпека підприємства - це забезпечення такого стану функціонування підприємства, який передбачає досягнення позитивного соціально-економічного ефекту шляхом одержання прибутку та задоволення потреб як споживачів, так і працівників підприємства [7].

Формування у підприємстві дієвої системи економічної безпеки і організація іiі успішної реалізації повинні базуватися на методологічних аспектах наукової теорії безпеки та включати певні заходи, що здійснюється поетапно в певній послідовності або одночасно. Їх сукупність утворює механізм забезпечення економічною безпекою підприємства як сукупність правових норм, законодавчих актів, спонукальних мотивів i стимулів, заходів, методів, засобів і сил, за допомогою яких забезпечується досягнення цілей безпеки і вирішення поставлених завдань.

Аналіз наукових досліджень різних дослідників-економістів свідчить про невизначену точку зору, щодо трактування поняття «механізм забезпечення економічної безпеки підприємства».

Так, Л.І. Донець та Н.В. Ващенко визначають, що дане поняття трактується як набір засобів, організація їх використання і контроль для досягнення високого рівня економічної безпеки підприємства [3].

Н.П. Левковець вважає, що механізм забезпечення економічної безпеки підприємства $є$ сукупністю нормативно-правових актів, заходів, методів, завдяки чому суб'єкт впливає на об'єкт з метою забезпечення безпеки та протидії загрозам [5].

І.Л. Шевченко у своїх дослідженнях зазначає, що механізм забезпечення економічної безпеки підприємства як набір методів і засобів, що, при взаємозв'язку з системою управління та контролю, забезпечують ії високий рівень [12].

Л.П. Гончаренко та Є.С. Куценко вважають, що механізм забезпечення економічної безпеки розглядається як ефективне використання корпоративних ресурсів підприємства для забезпечення його економічної безпеки. До таких ресурсів автори відносять персонал, капітал, технології, інформацію, техніку та ресурс прав [2].

С.П. Міщенко розглядає механізм формування економічної безпеки підприємства як взаємопов'язану сукупністю структур, методів, засобів і заходів, які формують безпеку підприємництва [8].

Найбільш повним та оптимальним варіантом визначення поняття «механізм 
забезпечення економічної безпеки» вважається розгляд його з урахуваннями галузевих особливостей підприємства як сукупності економічних, управлінських, правових, організаційних, мотиваційних шляхів взаємозв'язку інтересів підприємства з інтересами суб’ єктів зовнішнього середовища, за допомогою яких досягається одержання потрібного рівня прибутку для перебування в стані економічної безпеки [1].

Забезпечення економічної безпеки підприємства $\epsilon$ найважливішим завданням стратегічного планування. Задля цього та прогнозування ризиків і загроз суб'єкту господарювання має бути механізм забезпечення економічної безпеки, який повинен бути сформований з огляду на специфіку та вид діяльності підприємства, а також враховувати всі чинники та фактори впливу, які б дозволяли підтримувати його внутрішній потенціал на тому рівні, який потрібен для ефективного функціонування i реагування на негативні явища. Функціонування механізму забезпечення економічної безпеки підприємства повинно передбачати дієвий взаємозв'язок завдань і цілей на кожному рівні, обираючи, при цьому, оптимальні шляхи реалізації управлінських рішень.

Механізм забезпечення економічної безпеки має такі особливості:

1) динамічний характер стану захищеності;

2) врахування внутрішніх загроз, які є не менш небезпечними, ніж зовнішні;

3) державна система забезпечення безпеки повинна на правовій основі взаємодіяти з механізмом економічної безпеки.

Варто зазначити, що метою формування механізму управління економічною безпекою підприємства є забезпечення та підтримка належного рівня економічної безпеки, який дасть змогу досягти позитивного соціально-економічного ефекту шляхом одержання прибутку та задоволення потреб як споживачів, так i працівників підприємства.

Д.В. Дячков вважає, що метою механізму економічної безпеки підприємства є:

класифікація та формування економічних інтересів підприємства;

аналіз загроз економічній безпеці підприємства з внутрішнього та зовнішнього середовища;

протидія загрозам;

забезпечення розвитку підприємства відповідно обраній меті;

економічний захист усіх функціональних сфер діяльності підприємства [4].

Відповідно метою управління економічною безпекою підприємства $\epsilon$ забезпечення надійної захищеності життєво важливих інтересів і основ існування підприємства від внутрішніх i зовнішніх загроз, при якій у керівництва даного підприємства $\epsilon$ можливість самостійно визначати характер i форми діяльності, необхідної для забезпечення виробництва товарів і надання послуг в обсягах, що сприяють ефективному функціонуванню суб'єкта господарювання.

Доцільно констатувати, що забезпечення економічної безпеки підприємства повинно здійснюватися на двох рівнях:

1) оперативний рівень передбачає вирішення повсякденних господарських проблем, що поєднані з визначенням належного рівня вживання ресурсів, якими володіє підприємство;

2) стратегічний рівень забезпечує ухвалення максимально важливих управлінських рішень на довготривалий період. Однак крім зазначеного, 3 метою забезпечення економічної безпеки підприємства необхідно враховувати місце розташування підприємства, його трудовий потенціал, природні ресурси, компетентність працівників, рівень забезпечення населення тощо [13].

Не менш важливим питанням забезпечення економічної безпеки підприємства $\epsilon$ захист власності. Говорячи про формування цивілізованих ринкових взаємозв'язків, варто зазначити, що розробка механізмів є необхідним для формування відкритого i прозорого ринку, який не з'явиться сам по собі. Основою корупційної діяльності $\epsilon$ «зіткнення» бізнесу і влади. Тому механізм, з однієї сторони повинен вирішувати 
проблеми корупції, а з іншої - послаблювати бюрократичні бар'єри. Це, в свою чергу, вимагає вдосконалення організаційних, економічних та правових механізмів дії органів влади з метою усунення і запобігання умов й причин, які стимулюють виникнення i поширення корупційних схем.

Тактика забезпечення безпеки підприємства передбачає виконання конкретних дій і вживання конкретних процедур з метою забезпечення його економічної безпеки:

вживання додаткових заходів для збереження комерційної таємниці;

розширення юридичного відділу підприємства;

пред’явлення претензій контрагентові-порушникові;

створення відділу кібербезпеки;

звернення з позовом в правоохоронні і судові органи [11].

Найбільш значимим структурним елементом механізму управління економічною безпекою підприємства є системне забезпечення управління економічною безпекою підприємства, куди входить нормативно-правове, інформаційне, організаційне, методичне та ресурсне забезпечення.

До основних елементів механізму забезпечення економічної безпеки Ю.А. Локтіонова відносить [6]:

- прогнозування потенційних та виявлення реальних загроз і небезпек; впливу;

- пошук способів і методів їх запобігання, пом'якшення або ліквідації наслідків їх

- знаходження засобів і сил, які потрібні для забезпечення безпеки підприємства;

- організація взаємодії 3 контролюючими та правоохоронними органами для запобігання і припинення правопорушень, які можуть бути направлені проти інтересів підприємства; небезпекам.

- власна служба безпеки, створення якої у підприємстві запобігатиме загрозам і

Об'єктами управління економічною безпекою підприємства, які виступають одним із елементів досліджуваного механізму є:

- різноманітні види діяльності підприємства;

- ресурси і майно підприємства (матеріально-технічні, фінансові, інтелектуальні, інформаційні);

- працівники підприємства, акціонери, служби, різні структурні підрозділи і т.д.

Відповідно, суб'єктами є ті особи, служби, підрозділи, які безпосередньо займаються забезпеченням безпеки підприємства.

Розглянувши наведені вище визначення, варто зазначити, що механізм забезпечення економічної безпеки підприємства має виконувати наступні функції:

- аналіз загроз економічній безпеці внутрішнього та зовнішнього походження;

- формування та класифікація економічних інтересів підприємства;

- формування необхідного ресурсного потенціалу для забезпечення економічної безпеки підприємства;

- прогнозування, планування (тактичне і стратегічне) економічної безпеки; підприємства;

- планування (тактичне і стратегічне) виробничо-господарської діяльності

- функціональний аналіз рівня економічної безпеки підприємства;

- оцінка стану та діагностика досягнутого рівня економічної безпеки тощо.

Відповідно основними завданнями, які $\epsilon$ елементом механізму забезпечення економічної безпеки будь-якого господарюючого суб'єкту є:

- захист інтересів і законних прав як підприємства загалом, так i його співробітників зокрема ;

- збір, аналіз, обробка даних і прогнозування розвитку діяльності; посади;

- постійний моніторинг конкурентів, партнерів, клієнтів та претендентів на

- постійний та своєчасний моніторинг потенційних загроз підприємству і його 
співробітникам зі сторони зовнішнього середовища;

- протидія проникненню структур організованої злочинності, економічної розвідки конкурентів i окремих осіб 3 протиправними намірами у діяльність підприємства;

- запобігання технічному проникненню в злочинних цілях у діяльність підприємства;

- захист персоналу підприємства від насильницьких посягань;

- збереження комерційної таємниці підприємства;

- отримання необхідної інформації для розробки найбільш оптимальних управлінських рішень;

- формування серед населення та ділових партнерів позитивного іміджу підприємства, що сприяє реалізації планів економічної діяльності та досягнення поставлених цілей; підприємства;

- технічна і фізична охорона будівель, споруд, транспортних засобів і площ

- контроль та моніторинг ефективності функціонування системи безпеки підприємства загалом та коригування і вдосконалення іiі елементів.

Зазначене вище дає можливість визначити чинники впливу на економічну безпеку, які в свою чергу варто поділити на внутрішні і зовнішні. Так, до внутрішніх відносимо: управлінські, фінансові, техніко-технологічні, виробничі, інноваційні, інформаційні, енергетичні, екологічні, юридичні, до зовнішніх - економічні, законодавчі, природні, ринкові, форс-мажорні, стейкхолдерські.

Методами забезпечення економічної безпеки підприємства доцільно визначити:

- збір, обробка інформації та прогнози розвитку економічної ситуації, враховуючи фактори зовнішнього і внутрішнього середовища;

- прогноз можливих небезпек і загроз підприємству, які можуть вплинути на його діяльність;

- прийняття управлінських рішень щодо мінімізації впливу або недопущення виявлених загроз;

- організацію діяльності з метою попередження можливих загроз;

- проведення практичного експерименту щодо перевірки ефективності відпрацьованих моделей (алгоритмів);

- попереднє формування моделей та розробка алгоритмів з метою супротиву негативного впливу небезпекам і загрозам щодо діяльності підприємства;

- виявлення, аналіз і оцінка реальних загроз економічній безпеці, що уже виникли;

- ухвалення управлінських рішень і організація діяльності з реагування на загрози, що уже виникли;

- застосування відпрацьованих моделей на практиці;

- аналіз та оцінка ефективності реалізації прийнятих управлінських рішень;

- корегування системи протидії загрозам і небезпекам;

- постійне покращення системи забезпечення економічної безпеки [9].

Основними загальними принципами механізму визначено принципи системності, обгрунтованості, гнучкості та адаптивності, комплексності, своєчасності, економічної доцільності, законності, відповідальності. Специфічними принципами є: диференціації, варіантності, спеціалізації, достатності, безперервності, економії ресурсів, повної підконтрольності, конвергентності, прийнятного ризику, компетентності, прогресивності та результативності, утримання стійкості. Дані принципи повинні у бути взаємопов'язаними, тобто мати системний характер, оскільки недотримання хоча б одного із них може негативно вплинути на ефективність і результативність функціонування механізму забезпечення економічної безпеки підприємства.

А отже, ефективне функціонування механізму забезпечення економічної безпеки підприємства дасть можливість налагодити процес надходження ринкової інформації та ресурсів, виробництво високоякісної i мінімізацію витрат, підвищення рівня 
спеціалізації виробництва вцілому і працівників зокрема, використання засобів забезпечення безпеки підприємств і передових охоронних систем [10].

Висновки. Таким чином, підсумком об'єднання і систематизації усіх елементів системи економічної безпеки стане механізм забезпечення економічної безпеки підприємства, який спрямований на ефективну діяльність підприємства загалом. 3 метою ефективного забезпечення економічної безпеки доцільно використовувати системний підхід 3 дієвим комплексним взаємозв'язком усіх факторів, чинників і умов діяльності підприємства.

\section{Список бібліографічного опису}

1. Білошкурська Н.В. Економіко-організаційний механізм формування економічної безпеки підприємства : принципи побудови, функції, структура. Економіка та держава. 2013. № 12. С. 24-29.

2. Гончаренко Л.П., Куценко Е.С. Управление безопасностью : уч. пособ. М. : КНОРУС, 2005. 272 с.

3. Донець Л.І., Ващенко Н.В. Економічна безпека підприємства : навч. посіб. К. : ЦУЛ, 2008. 240 с.

4. Дячков Д.В., Батура В.Ю., Сокирко I.А. Формування організаційно-економічного механізму управління економічною безпекою підприємства. Вчені записки ТНУ імені В. І. Вернадського. Серія : Економіка та управління. К. : ВД «Гельветика», 2019. Т. 30 (69). № 5. Ч. 2. С. 31-36.

5. Левковець Н.П. Принципи забезпечення економічної безпеки підприємства. Управління проектами, системний аналіз і логістика : науковий журнал. 2008. № 5. С. 333-336.

6. Локтионова Ю.А. Механизм обеспечения экономической безопасности предприятия. Сочиально-экономические явления и процессы. 2013. № 3 (49). С. 93-99.

7. Маркіна І.А., Потапюк І.П. Загрози економічній безпеці підприємства: теоретичний аспект. Вісник Приазовського державного технічного університету. Серія : економічні науки. Маріуполь, 2017. С. 130-137.

8. Міщенко С.Г. Економіко-статистичний аналіз факторів економічної безпеки регіону. Вісник Донецького університету. Серия В «Економіка і право». 2009. № 1. С. 70-76.

9. Орлик О. Економічна безпека підприємства : властивості, стратегія та методи забезпечення. Економічна безпека в умовах глобалізаиї̈ світової економіки : колект. моног. у 2 т. Дніпропетровськ : «ФОП Дробязко С.І.», 2014. Т. 2. С. 176-182.

10. Протопопова Н.А. Механізм забезпечення економічної безпеки промислових підприємств. Системи обробки інформаиіï. 2010. Вип. 3. С. 150-151.

11. Торкатюк B.I., Аболхасанзаде А., Мітіна Т.В., Козинська І.О., Кузічкіна Н.І., Дріль Н.В. Механізм забезпечення економічної безпеки підприємств. URL: http://eprints.kname.edu.ua/38672/1/164-165.pdf

12. Шевченко І.Л. Особливості формування механізму забезпечення економічної безпеки металургійних підприємств. Стратегія економічного розвитку України. 2009. Вип. 24-25. С. 128-134.

13. Юрович Л. Економічна безпека підприємства : сутність, чинники впливу, основні проблеми. 66-та студентська науково-технічна конференція. Секиія «Економіка і менеджмент» : зб. тез доп. Львів : В-во НУ «Львівська політехніка», 2009. С. 234-237.

\section{References}

1. Biloshkurs'ka N.V. Ekonomiko-orhanizatsiynyy mekhanizm formuvannya ekonomichnoyi bezpeky pidpryyemstva : pryntsypy pobudovy, funktsiyi, struktura. Ekonomika ta derzhava. 2013, no. 12, pp. 24-29. [In Ukrainian].

2. Goncharenko L.P., Kutsenko E.S. Upravlenie bezopasnostyu. M. : KNORUS, 2005. 272 p. [In Russian]

3. Donets' L.I., Vashchenko N.V. Ekonomichna bezpeka pidpryyemstva. K. : TsUL, 2008. 240 p. [In Ukrainian].

4. Dyachkov D.V., Batura V.Yu., Sokyrko I.A. Formuvannya orhanizatsiyno-ekonomichnoho mekhanizmu upravlinnya ekonomichnoyu bezpekoyu pidpryyemstva. Vcheni zapysky TNU imeni V. I. Vernads'koho. Seriya : Ekonomika ta upravlinnya. K. : VD «Hel'vetyka», 2019, T. 30 (69), no. 5, ch. 2. pp. 31-36. [In Ukrainian].

5. Levkovets' N.P. Pryntsypy zabezpechennya ekonomichnoyi bezpeky pidpryyemstva. Upravlinnya proektamy, systemnyy analiz i lohistyka : naukovyy zhurnal. 2008, no. 5. pp. 333-336. [In Ukrainian].

6. Loktionova Yu.A. Mehanizm obespecheniya ekonomicheskoy bezopasnosti predpriyatiya. Sotsialno-ekonomicheskie yavleniya i protsessyi. 2013, no. 3 (49), pp. 93-99. [In Russian]

7. Markina I.A., Potapiuk I.P. Zahrozy ekonomichniy bezpetsi pidpryyemstva : teoretychnyy aspekt. Visnyk Pryazovs'koho derzhavnoho tekhnichnoho universytetu. Seriya : ekonomichni nauky. Mariupol'. 2017, pp. 130-137. [In Ukrainian].

8. Mishchenko S.H. Ekonomiko-statystychnyy analiz faktoriv ekonomichnoyi bezpeky rehionu. Visnyk Donets'koho universytetu. Seryya V «Ekonomika i pravo. 2009, no. 1, pp. 70-76. [In Ukrainian].

9. Orlyk O. Ekonomichna bezpeka pidpryyemstva : vlastyvosti, stratehiya ta metody zabezpechennya. Ekonomichna bezpeka v umovakh hlobalizatsiyi svitovoyi ekonomiky : kolekt. monoh. u 2 t. Dnipropetrovs'k : «FOP Drobyazko S.I.», 2014, no. 2, pp. 176-182. [In Ukrainian].

10. Protopopova N.A. Mekhanizm zabezpechennya ekonomichnoyi bezpeky promyslovykh pidpryyemstv. Systemy obrobky informatsiyi. 2010, no. 3, pp. 150-151. [In Ukrainian].

11. Torkatyuk V.I., Abolkhasanzade A., Mitina T.V., Kozyns'ka I.O., Kuzichkina N.I., Dril' N.V. Mekhanizm zabezpechennya ekonomichnoyi bezpeky pidpryyemstv. Available at: http://eprints.kname.edu.ua/38672/1/164-165.pdf (accessed 12.09.2020) [In Ukrainian].

12. Shevchenko I.L. Osoblyvosti formuvannya mekhanizmu zabezpechennya ekonomichnoyi bezpeky metalurhiynykh pidpryyemstv. Stratehiya ekonomichnoho rozvytku Ukrayiny. 2009, no. 24-25, pp. 128-134. [In Ukrainian].

13. Yurovych L. Ekonomichna bezpeka pidpryyemstva : sutnist', chynnyky vplyvu, osnovni problemy. 66-ta student.s'ka naukovo-tekhnichna konferentsiya. Sektsiya «Ekonomika i menedzhment» : zb. tez dop. L'viv : V-vo NU «L'vivs'ka politekhnika», 2009, pp. 234-237. [In Ukrainian].

Дата подання публікації 23.09.2020 p. 